\title{
Solid-state fermentation of paper sludge to obtain spores of the fungus Trichoderma asperellum
}

\author{
Rosa Dorta-Vásquez, Oscar Valbuena and Domenico Pavone-Maniscalco*
}

\begin{abstract}
Paper_production generates large quantities of a solid waste known as papermaking sludge (PS), which needs to be handled properly for final disposal. The high amount of this byproduct creates expensive economical costs and induces environmental and ecological risks. Therefore, it is necessary to search uses for PS, in order to reduce the negative environmental impact and to generate a more valuable byproduct. Due to the cellulolytic composition of PS, this work evaluated a solid state fermentation process using it as substrate to obtain spores of the fungus Trichoderma asperellum. Optimal conditions to obtain T. asperellum spores were: $60 \%$ water content, $3 \%(\mathrm{w} / \mathrm{w})$ salts (Nutrisol $\mathrm{P}^{\circ}$ and Nutrisol $\mathrm{K}^{\circ}$ ), inoculum concentration at $1 \mathrm{x} 10^{5} \mathrm{spores} / \mathrm{g}$, and pasteurized or sterilized PS. Under these conditions it was possible to obtain $2.37 \times 10^{9}$ spores $/$ g. T. asperellum spores applied directly to pepper (Capsicum anuum) seeds without PS increased significantly seedling dry mass in greenhouse assays. This work suggests an alternative, economic and abundant substrate for production of T. asperellum spores.
\end{abstract}

Keywords: Papermaking sludge, cellulose, water activity, Capsicum anuum

Centro de Biotecnología Aplicada, Departamento de Biología, Facultad de Ciencias y Tecnología (FACYT), Universidad de Carabobo, Valencia, Venezuela

*Corresponding author: D. PavoneManiscalco

E-mail: dfpavone@gmail.com

DOI: 10.2478/ebtj-2019-0008
(C) 2019 Authors. This work was licensed under the Creative Commons AttributionNonCommercial-NoDerivs 4.0 License.

\section{Introduction}

The papermaking process generates large quantities of waste known as paper sludge (PS), which is basically composed of cellulose fibers unsuitable for papermaking. Disposal of PS has become an environmental and social problem $(1,2)$ due to physical-chemical and mechanical characteristics and decomposition processes. Additionally, high costs associated to transport of sludge and payments of taxes for discharge in landfills, have led to consider alternatives for its use.

Final disposal of PS in a sustainable way represents a challenge for all paper manufacturing companies around the world. Several reuse options have been proposed for PS, which include composting, production of commodities such as clay bricks, oil absorbent, animal feed formulations, lime, cellulases, fuels, carbon source in fermentations, etc., $(3,4,5,6,7$, $8,9,10,11,12,13,14,15)$. These alternatives should consider not only the use of PS as raw material, but must also be compatible with disposal costs in landfills to be attractive to industry and satisfy the adequate processing of the huge quantities of PS produced, according to principles of circular economy (16) for sustainable development.

The high content of cellulose in PS, could offer an alternative carbon source for biotechnological processes using cellulolytic microorganisms. Several species of the fungus Trichoderma, besides the cellulolytic capacity $(17,18,19)$ are also excellent biocontrol agents of phytopathogenic fungi, plant growth inducers and resistance stimulators, among other properties $(20,21,22)$. Thus, PS could be used as a carbon source for mass production of Trichoderma. In previous work (23) PS was used to obtain Trichoderma reseei biomass, obtaining relatively low yields $\left(2.28 \times 10^{8}\right.$ spores/g) compared to other substrates. 
Therefore, the aim of this study was to optimize the Trichoderma mediated fermentations process using PS as sole carbon source. Parameters such as water content, salt concentration, heat treatment, spore concentration and its effect on the germination and growth of Capsicum anuum were evaluated.

\section{Materials and Methods \\ Biological material}

Strain TV190 (Trichoderma asperellum) from corn fields of Venezuela, was used for this work. The strain was isolated and molecularly identified in Centro de Biotecnología Aplicada, Departamento de Biología, Facultad de Ciencias y Tecnología, Universidad de Carabobo (24). For greenhouse assays, Capsicum anuum seeds Conquistador variety (Brimport brand, Lot \# 1228-8541 02/13), were used.

\section{Paper sludge (PS)}

Paper sludge was obtained from the Liquid Effluent Treatment Plant of the Hygienic Division of "Manufacturas de Papel CA (MANPA) SACA", a manufacturing paper company located at Maracay, Aragua State, Venezuela.

\section{Water adsorption isotherm of PS}

PS samples with different water contents were used to determine water activity $\left(\mathbf{a}_{\mathrm{w}}\right)$, using a Model CX2 water activity meter, Decagon Devices. After obtaining $\mathrm{a}_{\mathrm{w}}$ values, water content was measured for each sample with a moisture analyzer Mettler, Model LJ16. Data were used to graph the water adsorption isotherm correlating water content to water activity at constant temperature $\left(27^{\circ} \mathrm{C}\right)$.

\section{Inoculum production of $T$. asperellum}

The inoculum used for solid state fermentation process (SSF) was prepared from PDA (potato dextrose agar, HiMedia) cul- tures incubated for eight days at $27^{\circ} \mathrm{C}$. A solution of $0.1 \%(\mathrm{w} / \mathrm{v})$ Tween 80 was added to sporulated culture. Concentration of spore suspensions was determined using a Neubauer chamber and adjusted according to the required concentration in each experiment.

\section{Solid state fermentation (SSF)}

To carry out SSF, the PS was hydrated, supplemented with salts and sterilized at $121^{\circ} \mathrm{C}, 15$ psi during 15 minutes. Finally, 15 $\mathrm{g}$ of this preparation were inoculated with an aliquot of T. asperellum spore suspension. The water content, the salts Nutrisol $\mathrm{P}^{\circ}(\mathrm{NP})$ and Nutrisol K $\mathrm{K}^{\circ}$ (NK) (Agromarketing C.A. Guacara, Venezuela; Table 1) and T. asperellum spore concentration are detailed for each experiment in the figure legends. Fermentation process was carried out in aluminum trays $(15 \times 20 \mathrm{~cm})$ placed inside transparent plastic bags. After incubation at $27^{\circ} \mathrm{C}$ for 7 days, the fermented paper sludge (FPS) was suspended and washed twice with a $0.1 \%(\mathrm{w} / \mathrm{v})$ Tween $80^{\circ}$ solution. Spore concentration was determined using a Neubauer chamber. Five replicates of each treatment were performed. Results were expressed in spores/g of dry PS.

\section{Greenhouse assays}

Fermented and sporulated paper sludge (FPS) was mixed with soil at a ratio of 1:2 in germination trays. A C. anuum seed was planted in each well $(2 \times 2 \times 4 \mathrm{~cm})$. It was included a treatment without FPS, in which seeds were submerged in a T. asperellum spore suspension $\left(10^{7}\right.$ spores $\left./ \mathrm{mL}\right)$ for one hour. Soil was obtained from the Lake of Valencia basin in "Manufacturas de Papel CA (MANPA) SACA". Fifty seeds per treatment were used.

\section{Determination of C. anuum growth}

Germinated seeds were counted daily. At the end of the test (45 days), aerial and root dry biomasses were determined. Roots

Table 1. Composition of soluble agricultural fertilizers Nutrisol $\mathrm{P}^{\circ}$ and Nutrisol $\mathrm{K}^{\circ}$

\begin{tabular}{|c|c|c|}
\hline Component & Nutrisol $\mathrm{P}^{\circ}(\% \mathrm{w} / \mathrm{w})$ & Nutrisol $K^{\circ}(\%$ w/w) \\
\hline $\mathrm{N}$ & 16 & 12 \\
\hline $\mathrm{P}_{2} \mathrm{O}_{5}$ & 40 & 2 \\
\hline $\mathrm{K}_{2} \mathrm{O}$ & 0 & 40 \\
\hline $\mathrm{MgO}$ & 0.2 & 0.5 \\
\hline $\mathrm{S}$ & 0.4 & 0.77 \\
\hline $\mathrm{Cu}$ & 0.02 & 0.02 \\
\hline $\mathrm{Zn}$ & 0.1 & 0.1 \\
\hline $\mathrm{Fe}$ & 0.03 & 0.03 \\
\hline $\mathrm{Mn}$ & 0.05 & 0.05 \\
\hline B & 0.04 & 0.04 \\
\hline Mo & 0.005 & 0.005 \\
\hline
\end{tabular}


were separated from soil carefully by washing with tap water. Aerial and root parts were dried at $60{ }^{\circ} \mathrm{C}$ until constant weight and dry biomass determined.

\section{Statistical analysis}

Descriptive statistics were applied to whole data, reporting mean and standard error. An exponential regression was applied to water adsorption isotherm to obtain an equation that relates water content to water activity for PS at $27^{\circ} \mathrm{C}$. Additionally, ANOVA and Tukey means comparison test were performed to verify significant differences between treatments. All experiments were repeated at least twice. The program Statistix v 8 was used.

\section{Results}

\section{Water adsorption isotherm}

The water adsorption isotherm is shown in Fig. 1, in which for water content values greater than $30 \%$, water activity $\left(\mathrm{a}_{\mathrm{w}}\right)$ is above 0.95 , enough to support Trichoderma growth (26). From exponential regression, an equation was obtained $\left(w_{c}=0.421 e^{4.3442 a w}\right)$ relating water content to water activity. In this sense, it is possible to calculate water activity from water content data. According to this, and to guarantee appropriated conditions for the Trichoderma/PS fermentations, it is necessary to adjust water content to a minimum of $30 \%$.

\section{Solid State Fermentation (SSF).}

Water content. T. asperellum growth was evident in the 30-90 $\%$ of water content; at $10 \%$ no growth was observed. The higher yields were obtained at water contents of 60 and $70 \%\left(1.42 \times 10^{9}\right.$ spores/g) (Fig. 2), showing significant differences compared with the other treatments $(\mathrm{p}=0.0005)$. At water contents of
80 and $90 \%$, yield decreased to $7.65 \times 10^{8}$ and $8.7 \times 10^{8}$ spores/g, respectively.

Mineral salt content. In Fig. 3, higher yields were obtained at salt concentrations of 3 and $4 \%\left(2.17 \times 10^{9}\right.$ and $2.23 \times 10^{9}$ spores/g, respectively) and significant differences were observed respect to other treatments $(p=0)$. Besides, in treatments without salts, no growth was observed (data not shown).

Inoculum concentration. To determine the amount of inoculum necessary for a uniform growth of T. asperellum, the optimal inoculum concentration was determined. No significant differences $(\mathrm{p}=0.2185)$ were detected in the range of yield values between $1.14 \times 10^{9}$ and $2.20 \times 10^{9}$ spores/g (Fig. 4). Although differences among treatments were not detected, the highest yield was obtained using as inoculum $2 \times 10^{5}$ spores $/ g$.

Heat treatment to prepare substrate. In these experiments, several heat treatments were applied to PS (Fig. 5), obtaining significant differences $(\mathrm{p}=0)$. Treatment $\mathrm{B}$ (PS sterilized) and C (PS pasteurized) rendered the highest yields $\left(1.40 \times 10^{9}\right.$ and $1.07 \times 10^{9}$ spores / g, respectively). Based on these assays, it seems desirable to submit the substrate to pasteurization (100 ${ }^{\circ} \mathrm{C} / 30 \mathrm{~min}$ ), previously to the fermentative process.

\section{Greenhouse assays}

The seed germination started after 9 days and culminated the $24^{\text {th }}$ day. No differences in the germination time and number of germinated seeds were detected, under the different used conditions (data not shown). The aerial and root dry biomass in C. anuum under different cultivation conditions are shown in

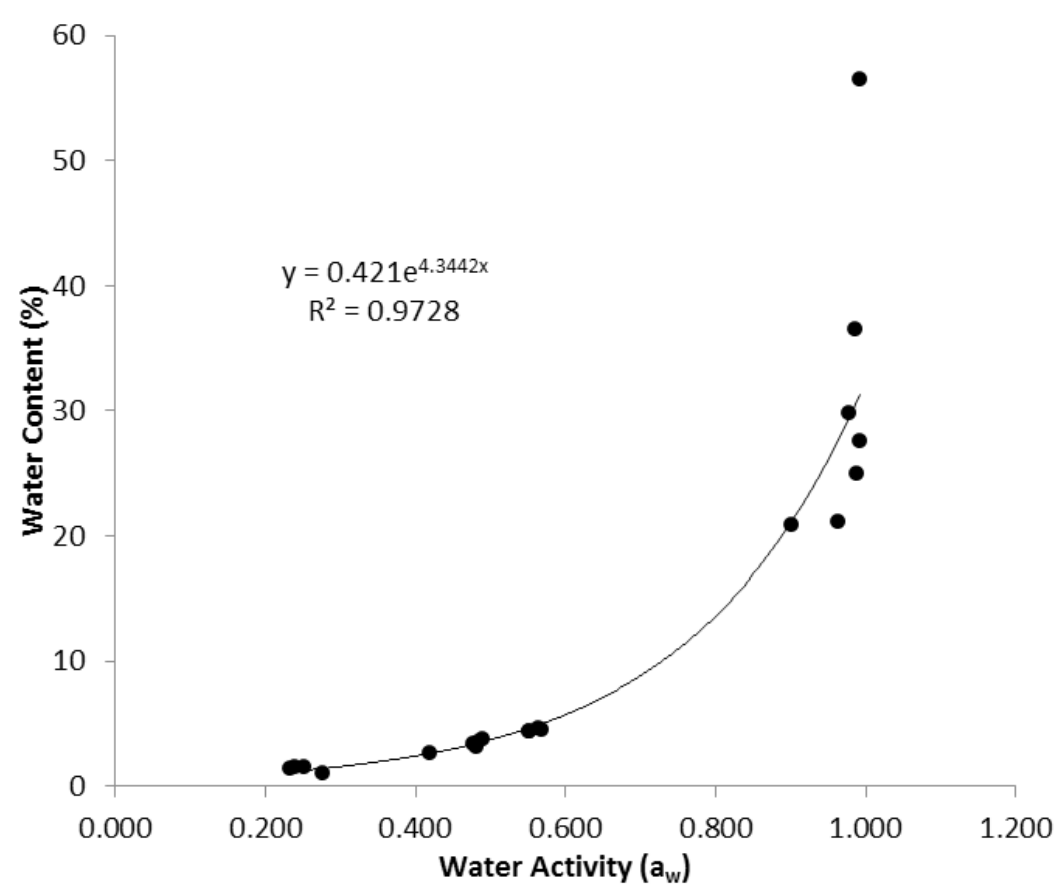

Figure 1. Water adsorption isotherm for papermaking sludge at $27^{\circ} \mathrm{C}$. 


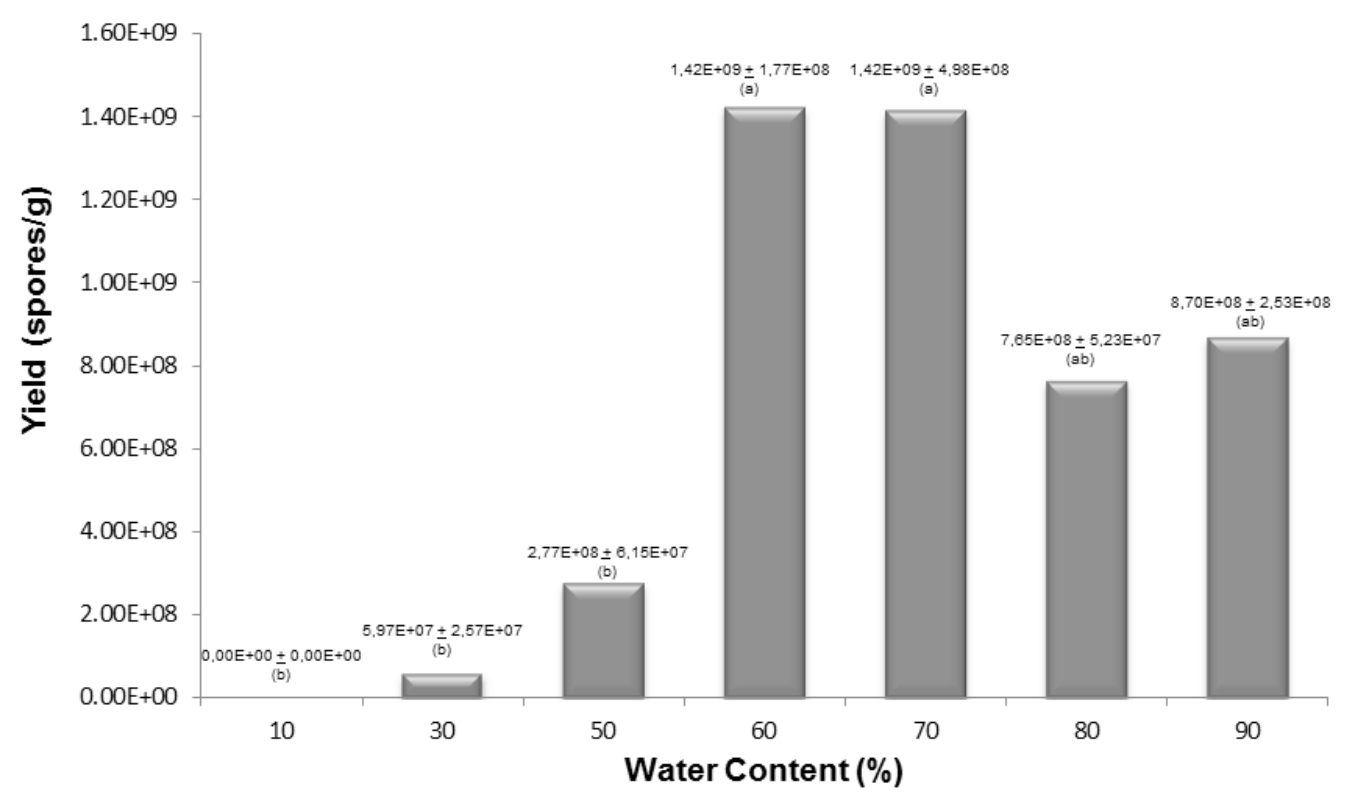

Figure 2. Spore yield of T. asperellum at different water contents on PS. 3\% (w/w) mineral salts (NP/NK). Substrate was sterilized (121 ${ }^{\circ} \mathrm{C} / 15 \mathrm{~min}$ ) and inoculated with $10^{6} \mathrm{spores} / \mathrm{g}$ ). Treatments with the same letter indicate no significant differences.

Table 2. These values indicated increments of 3 times over the correspondent A treatment values (14.42/4.62 and 6.39/2.11). Statistical analysis for aerial and root biomasses, revealed significant differences between treatments $(\mathrm{p}=0)$. The $\mathrm{D}$ treatment showed the highest value for both aerial and root biomasses (14.42 and $6.39 \mathrm{mg}$, respectively). Unexpected, in the $\mathrm{C}$ treatment containing FPS, the increase of biomass reached values of 7.07 and $3.76 \mathrm{mg}$ for aerial and root respectively, representing half of the values in $\mathrm{D}$ treatment. No differences were found among treatments $\mathrm{A}, \mathrm{B}$ and $\mathrm{C}$ for root biomass.

\section{Discussion}

In SSF, one of the most important parameters is water content which could become a limiting factor due to the low humidity characteristic of these systems. However, water content per se does not necessarily provide relevant information about water availability for microbial growth, since there may be substrates with low water availability having relatively high water content. In other words, the relationship between both parameters is not linear. This fact may cause limitations on microorganism growth, because filamentous fungi require high levels of $\mathrm{a}_{\mathrm{w}}$

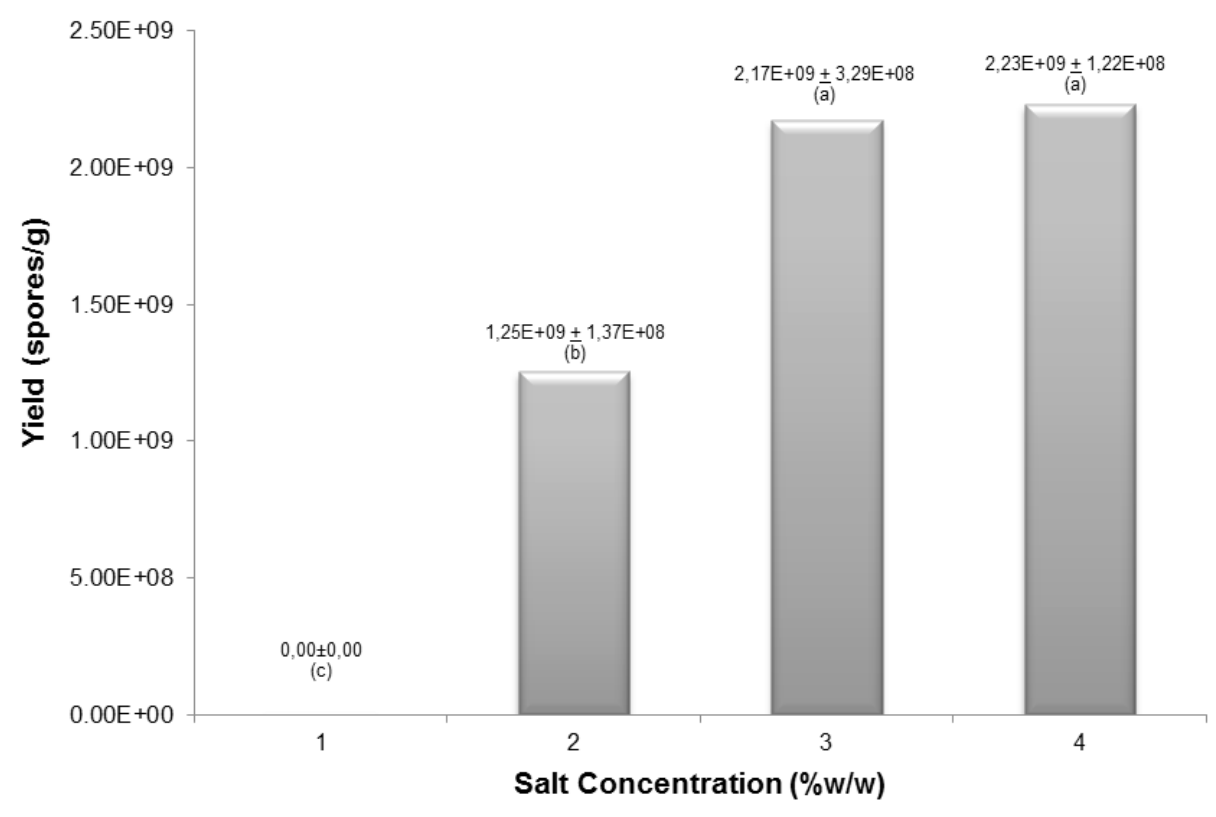

Figure 3. Spore yield of T. asperellum at different salt concentrations and PS as carbon source. Substrate was hydrated at $60 \%$, sterilized $\left(121^{\circ} \mathrm{C} / 15 \mathrm{~min}\right.$ ) and inoculated with $10^{6} \mathrm{spores} / \mathrm{g}$. Treatments with the same letter indicate no significant differences. 


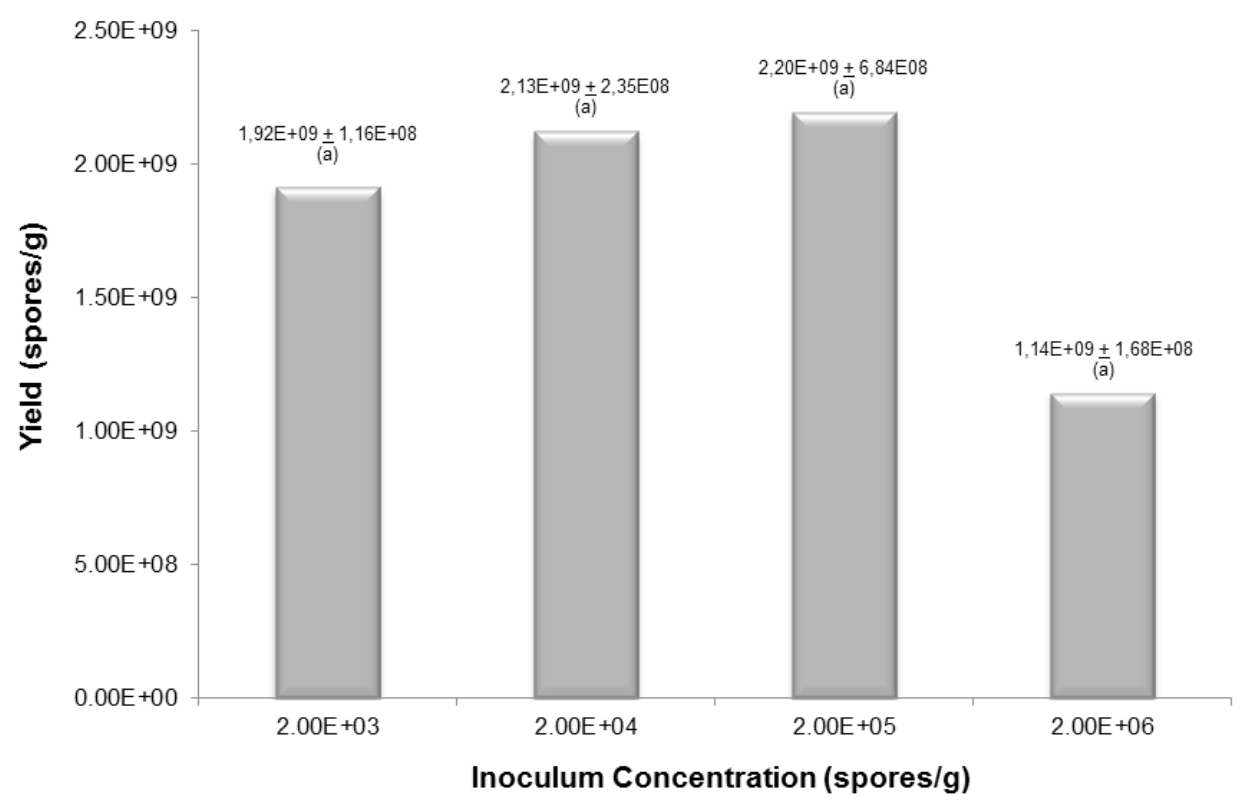

Figure 4. Spore yield of T. asperellum using different inoculum concentrations. Substrate was hydrated at $60 \%$, sterilized $\left(121{ }^{\circ} \mathrm{C} / 15\right.$ $\mathrm{min}$ ) and $3 \% \mathrm{w} / \mathrm{w}$ salt content (NP/NK). Treatments with the same letter indicate no significant differences.

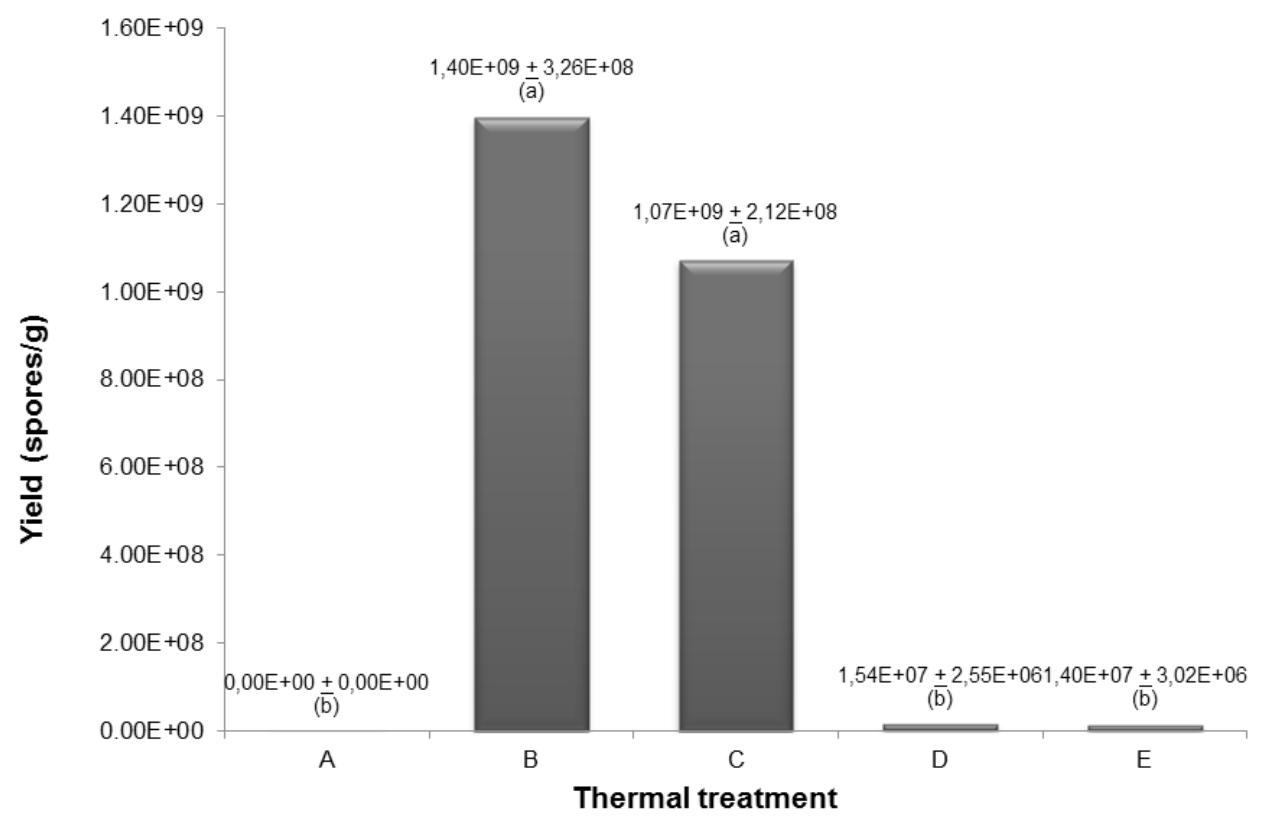

Figure 5. Spore yield of T. asperellum using different heat treatments. Substrate was hydrated at $60 \%$, inoculated with $10^{6} \mathrm{spores} / \mathrm{g}$ and $3 \% \mathrm{w} / \mathrm{w}$ salt content (NP/NK). Treatments with the same letter indicate no significant differences. A: Non-sterile PS dried at 60 ${ }^{\circ} \mathrm{C}$; B: Sterilized PS $\left(121^{\circ} \mathrm{C} / 15 \mathrm{~min}\right)$ previously dried at $60^{\circ} \mathrm{C} ; \mathrm{C}$ : Pasteurized PS $\left(100^{\circ} \mathrm{C} / 30 \mathrm{~min}\right)$ previously dried at $60^{\circ} \mathrm{C} ; \mathrm{D}:$ Air dried PS without sterilization; E: Non processed PS.

Table 2. Aerial and root dry biomass of $C$. anuum seedlings

\begin{tabular}{l|c|c}
\multicolumn{1}{c|}{ Treatment } & Aerial dry mass (mg) & Root dry mass (mg) \\
\hline (A) Soil & $4.62 \pm 0.22 \mathrm{c}$ & $2.11 \pm 0.11 \mathrm{~b}$ \\
\hline (B) Soil + Sterilized PS (SPS) & $6.29 \pm 1.21 \mathrm{~b}(1.36)$ & $3.28 \pm 0.67 \mathrm{~b}(1.55)$ \\
\hline (C) Soil + Fermented PPS (FPS) & $7.07 \pm 0.26 \mathrm{~b}(1.53)$ & $3.76 \pm 0.15 \mathrm{~b}(1.78)$ \\
\hline (D) Seed + TV190, without PS & $14.42 \pm 1.54 \mathrm{a}(3.12)$ & $6.39 \pm 0.54 \mathrm{a}(3.03)$ \\
\hline
\end{tabular}


for growth on solid media (25). Therefore, it is important to determine optimal water activity in SSF. In this work we reported a relationship between $\mathrm{w}_{\mathrm{c}}$ and $\mathrm{a}_{\mathrm{w}}$ for PS. Similar water activity values were reported in SSF using PS under anaerobiosis with Clostridium thermocellum 27405 to obtain lactate, ethanol and acetate (27). Although isotherm realized by these authors does not cover the same water contents as in our work, the same minimum water content was recommended to obtain adequate water availability in the process. By using a wider range of water content in this work, it was possible to obtain an equation that correlates water content to water activity for PS. It has been reported that using Trichoderma in SSF at 70\% water content induced greater sporulation (28). SSF with very low humidity reduced water availability and nutrient solubility, while very high water content decreased interparticle airspace causing a lower oxygen transfer, phenomenon previously observed (27), determining that increases in water content in solid cultures, improved the performance of the anaerobic bacterium $C$. thermocellum. In this way, it was decided to continue this work using a water content of $60 \%$ to avoid limitations due to water excess or defect.

It has been determined the feasibility of SSF using PS as substrate to obtain Trichoderma spores (23). However, these processes gave lower yields than those obtained with other conventionally substrates (rice and corn) for mass production of Trichoderma in our Laboratory. Therefore, for increasing the biomass yields in this system, different parameters such as mineral salts content, spore inoculum concentration and heat treatment were evaluated. Previous report (23) indicated that PS should be supplemented with salts in order to support Trichoderma growth. This fact was evident in our work from treatment with no salt in which growth was not observed. For industrial processes, media components must guarantee economic feasibility. In this sense, agricultural fertilizers NP and NK were used to amend PS. The relative proportions among some elements, particularly the $\mathrm{C} / \mathrm{N}$ ratio is important for the fungal growth (29). In the case of Trichoderma spp, various studies have recommended optimal values of $\mathrm{C} / \mathrm{N}$ ratio between 6 and $26(30,31)$. It has been suggested that sporulation is more affected by $\mathrm{C}: \mathrm{N}$ ratio than by $\mathrm{C}$ and $\mathrm{N}$ concentration per se, being this ratio for Trichoderma viride 10:1 (32). In our case, considering the $\mathrm{N}$ content in $\mathrm{NP}$ and $\mathrm{NK}$, the optimal $\mathrm{PS} / \mathrm{N}$ ratio was 17.5. Fertilizers NP and NS, supplied not only nitrogen but also crucial elements for fungal growth like phosphorus, potassium, sulphur and magnesium, among others. Another parameter for an optimal SSF is inoculum concentration, which must be enough to obtain homogenous and fast substrate colonization. In SSF using rice (33), no significant differences in yields were reported by varying inoculum of Trichoderma $s p$. from $1 \times 10^{6}$ to $1 \times 10^{8}$ spores/g). In the range of inoculum concentrations of $2 \times 10^{3}$ and $2 \times 10^{6}$ spores/g, we did not observe differences in yield; this could be due to the fast and abundant growth characteristic in Trichoderma. For industrial processes, it is necessary to determine costs of inoculum production in order to make a decision relating optimal growth and economy. For mass production processes, sterilization treatment could result in higher production costs; therefore, pasteurizing rather than sterilizing, could make the process more profitable. According to our data, it is enough to pasteurize PS to initiate a SSF using T. asperellum. Our work suggest that PS, an economic and abundant carbon source, could be used in SSF to produce $T$. asperellum spores in industrial processes, although spore recovery after fermentation, final formulation, storage stability, as well as economic feasibility, need more research.

To assess the effect of fermented PS on the C. anuum seedlings growth, it was used as amend to soil and three parameters were determined: the number of germinated seeds and the aerial and root dry mass. No differences in germination rate were detected, which may be explained assuming that seed germination depends basically on the nutrients inside the seed, the appropriate temperature and water availability. External nutrients seems no exert important effects on the seed germination in C. anuum. Aerial and root dry mass values demonstrated that $T$. asperellum stimulated seedlings growth, which have been reported by (34) working with tomato, brinjal, chilli, okra, ridge gourd and guar, suggesting that seed germination and development is dose dependent. In other work (35) using several isolates of Trichoderma spp., it has been reported an increased in seedling development of C. anuum. Similarly, working with pepper plants in greenhouse, an increase in growth using native strains of Trichoderma spp has been reported (36). Applications of Trichoderma spp. in different cultures generally resulted in more vigorous plants, with greater weight and root development $(37,38)$ which depends on inoculum and substrate type (39). Notably, the lower growth observed with FPS, could have been due to a relative high amount of it in the small spaces of the germination wells. Also, the addition of FPS to soil and not directly to seed could reduce contact, decreasing its effect on seedling development. The results suggest that it is better to apply T. asperellum spores directly to seed, and FPS directly to soil in field, although greenhouse and field assays are necessary.

\section{Conclusions}

Results obtained in this study corroborate that use of the PS is feasible to perform SSF for the production of fungal biomass (spores) of T. asperellum. Water adsorption isotherm for PS showed that values of at least 30\% water content are required to reach values of water activity greater than 0.95 needed for fungal growth. It was determined that with a water content at 60 to $70 \%$, salt $(\mathrm{NP} / \mathrm{NK})$ concentration at $3 \%(\mathrm{w} / \mathrm{w})$, inoculum concentration at $2 \times 10^{5}$ spores/g, and pasteurized or sterilized substrate, it is possible to obtain yields at $2 \times 10^{9}$ spores/g), comparable to those obtained with other substrates like rice. Downstream processes efficiency, cost studies and economic feasibility must be determined.

The better result for growing C. anuum plants, inoculations of seeds by submerging them in a spore suspension, significantly favors the C. anuum plant development. It is necessary to perform greenhouse and field assays, applying T. asperellum directly to seeds and transplanting seedlings adding FPS on soil. 


\section{Ackowledgment}

The authors wish to express their gratitude to Dr. Blas Dorta (IBEUCV) for his support in water adsorption isotherm determination; "Manufacturas de Papel C.A. (MANPA) S.A.C.A.", for donation of paper sludge used in this work and Agromarketing C.A. for donation of the salts (Nutrisol $\mathrm{P}^{\circ}$ and Nutrisol $\mathrm{K}^{\circ}$ ).

\section{Conflict of interest statement}

The authors declare no conflict of interest.

\section{References}

1. Martínez Y, Rivero C. Efecto del uso de lodo papelero sobre el contenido de N, P, K en dos suelos de importancia en la Cuenca del Lago de Valencia. Rev Tec Fac Ing Univ 2007; 30: 63-70.

2. Ochoa J. Feasibility of recycling pulp and paper mill sludge in the paper and board industries. Resour Conserv Recy 2008; 52(7): 965-972.

3. Shin C, Lee J, Lee J, Park S. Enzyme production of Trichoderma reesei Rut C-30 on various lignocellulosic substrates. Appl Biochem Micro 2000; 84-86: 237-245.

4. Lee $\mathrm{S}, \mathrm{Koo} Y$, Lin J. Production of lactic acid from paper sludge by simultaneous saccharification and fermentation. Adv Biochem Eng Biot 2004; 87: 173-194.

5. Quinchia A, Valencia M, Giraldo G. Uso de lodos provenientes de la industria papelera en la elaboración de paneles prefabricados para la construcción. Revista EIA 2007; 8: 9-19.

6. Garg V, Gupta. Stabilization of primary of sewage sludge during vermicomposting. J Hazard Mater 2008; 153: 1023-1038.

7. Hara K, Mino T. Environmental assessment of sewage sludge recycling options and treatment processes in Tokio. Waste Manage 2008; 28: 2645-2652.

8. Afridi H, Arain M, Jalbani N, Jamali M, Kazi T, Memon A, Shan A. Use of sewage sludge after liming as fertilizer maize growth. Pedosphere 2008; 18: 203-213.

9. Wang W, Kang L, Lee Y. Production of cellulase from kraft paper mill sludge by Trichoderma reesei rut C-30. Appl Biochem Biotech 2010; 161(1-8): 382-94.

10. García A, Rivero C. Efecto de la aplicación de lodos papeleros sobre los contenidos de carbono microbiano y la actividad de deshidrogenasa en suelos agrícolas. Venesuelos 2011; 18: 29-35.

11. Shen J, Agblevor F. Ethanol production of semi-simultaneous saccharification and fermentation from mixture of cotton gin waste and recycled paper sludge. Bioproc Biosyst Eng 2011; 34(1):33-43.

12. Chen H, Han Q, Daniel K, Venditti R, Jameel H. Conversion of industrial paper sludge to ethanol: fractionation of sludge and its impact. Appl Biochem Biotech 2014; 174(6): 2096-2113.

13. Gottumukkala L, Haigh K, Collard F, Van Rensburg E, Görgens J. Opportunities and prospects of biorefinery-based valorisation of pulp and paper sludge. Bioresource Technol 2016; 215: 37-49.

14. Donmez A, Yelb H, Boranc S, Pesmand E. Cement type composite panels manufactured using paper mill sludge as filler. Constr Build Mater 2017; 142: 410-416.

15. Lai T, Pham T, Adjallé K, Montplaisir D, Brouillette F, Barnabé S. Production of Trichoderma reesei RUT C-30 lignocellulolytic enzymes using paper sludge as fermentation substrate: An approach for on-site manufacturing of enzymes for biorefineries. Waste Biomass Valori 2017; 8 (4): 1081-1088.

16. Korhonen J, Honkasalo A, Seppälä J. Circular Economy: The Concept and its Limitations. Ecol Econ 2018; 143: 37-46.

17. Buchert J, Pere J, Ranua M, Siika-aho M, Viikari J. Trichoderma reesei cellulases in bleaching of kraft pulp. Appl Microbiol Biot 1994; 40: 941-945.

18. Argüello H, Castellanos D, Cruz N. Degradación de celulosa y xilano por microorganismos aislados de dos tipos de compost de residuos agrícolas en la sabana de Bogotá. Revista Colombiana de Ciencias Hortícolas 2009; 3 (2): 237-249.
19. Bischof R, Ramoni J, Seiboth B. Cellulases and beyond: the first 70 years of the enzyme producer Trichoderma reesei. Microb Cell Fact 2016; 15(1): 106.

20. Harman G. Myths and dogmas of biocontrol: Changes in perceptions derived from research on Trichoderma harzianum T-22. Plant Dis 2000; 84: 377-393.

21. Benítez T, Delgado J, Rey M, Rincón A, Limón M. Mejora de cepas de Trichoderma para su empleo como biofungicidas. Rev Iberoam Micol 2000; 17: 31-36.

22. Vos C, De Cremer K, Cammue B, De Coninck B. The toolbox of Trichoderma spp. in the biocontrol of Botrytis cinerea disease. Mol Plant Pathol 2015; 16(4): 400-412.

23. Centeno R, Pavone D. Producción de enzimas celulasas y biomasa del hongo Trichoderma reesei utilizando lodo papelero como fuente de carbono. Revista de la Sociedad Venezolana de Microbiología 2015; 35: 40-46.

24. Pavone D, Dorta B. Diversidad del hongo Trichoderma spp. en plantaciones de maíz de Venezuela. Interciencia 2015; 40(1): 2331.

25. Dorta B, Bosch A, Arcas J, Ertola R. High level of sporulation of Metarhizium anisopliae in a medium containing by-products. Appl Microbiol Biot 1990; 33: 712-715.

26. Fink S, Schubert M, Schwarse F. In vitro screening of an antaginisc Trichoderma strain against wood decay fungi. Arboricultural Journal 2008; 31: 227-248.

27. Chinn M, Nokes S, Strobel H. Influence of process conditions on end product formation from Clostridium thermocellum 27405 in solid substrate cultivation on paper pulp sludge. Bioresource Technol 2007; 98: 2184-2193.

28. Barzegar M, Hamidi Z, Latifian M (2007) Evaluation of culture conditions for cellulase production by two Trichoderma reesei mutants under solid-state fermentation conditions. Bioresource Technol 2007; 98: 3634-3637.

29. Gervais $P$, Molin P. The role of water in solid-state fermentation. Biochem Eng J 2003; 13(2-3):85-101.

30. Aceh D. Spore production of biocontrol agent Trichoderma harzianum: Effect of $\mathrm{C} / \mathrm{N}$ ratio and glucose concentration. Journal Rekayasa Kimia dan Lingkubga 2007; 6: 35-40.

31. Agosin E, Crawford A, Martin R, Mun G, Volpe D. Effect of culture conditions on spore shelf life of the biocontrol agent Trichoderma harzianum. World J Microb Biot 1997; 13: 225-232.

32. Gao L, Liu X. A novel two-stage cultivation method to optimize carbon concentration and carbon-to-nitrogen ratio for sporulation of biocontrol fungi. Folia Microbiol 2009; 54(2):142-6.

33. Castro B, Valencia J. Estudios de algunos aspectos biológicos de Trichoderma sp. antagónicos a Rosellinia bunodes. Cenicafé 2004; 55 (1): 16-28.

34. Singh V, Sanmukh R, Kumar B, Baha H. Trichoderma asperellum spore dose depended modulation of plant growth in vegetable crops. Microbiol Res 2016; 193: 74-86.

35. Herrera-Parra E, Cristóbal-Alejo J, Ramos-Zapata J. Trichoderma strains as growth promoters in Capsicum annuum and as biocontrol agents in Meloidogyne incognita. Chil J Agr Res 2017; 77(4) http://dx.doi.org/10.4067/S0718-58392017000400318.

36. González P, Guigón C. Selección de cepas nativas de Trichoderma spp. con actividad antagónica sobre Phytophthora capsici Leonian y promotoras de crecimiento en el cultivo de chile (Capsicum annuum L.). Revista Mexicana de Fitopatología 2004; 22: (1) 117 - 124.

37. Björkman T, Harman G, Mastouri F. Seed treatment with Trichoderma harzianum alleviates biotic, abiotic, and physiological stresses in germinating seeds and seedlings. Phytopathology 2010; 100 (11): $1213-1221$.

38. Crowley D, Yang C. Rhizosphere microbial community structure in relation to root location and plant iron nutritional status. Appl Environ Microb 2000; 66: 365 - 369.

39. Marín-Guirao J, Rodríguez-Romera P, Lupión-Rodríguez B, Camacho-Ferre F, Tello-Marquina J. Effect of Trichoderma on horticultural seedlings' growth promotion depending on inoculum and substrate type. J Appl Microbiol 2016; 121(4):1095-102. 